\title{
The disjunct distribution of Cladonia dimorphoclada Robbins (Ascomycota: Cladoniaceae): first record in South America
}

\author{
(Demerson Luiz Gumboski ${ }^{1,4}$, Adriano Afonso Spielmann², Luciana da Silva Canêz ${ }^{2}$, Kerolayne Gonçalves ${ }^{3}$ \\ and Neli Kika Honda ${ }^{3}$
}

Received: 4.04.2018; accepted: 8.08.2018

\begin{abstract}
The disjunct distribution of Cladonia dimorphoclada Robbins (Ascomycota: Cladoniaceae): first record in South America). Previously known only from the North and Central America, the lichenized fungi Cladonia dimorphoclada Robbins is recorded for the first time in South America. The specimens were found growing on soil, in an open area at 1695 $\mathrm{m}$ alt., in Southern Brazil. We present a distribution map, figures, and comments.
\end{abstract}

Keywords: Atlantic Forest, biodiversity, fungi, high altitude fields, lichen

RESUMO - (Distribuição disjunta de Cladonia dimorphoclada Robbins (Ascomycota: Cladoniaceae): primeiro registro para a América do Sul). Conhecida previamente apenas para América do Norte e Central , o fungo liquenizado Cladonia dimorphoclada Robbins é registrada pela primeira vez para a América do Sul. Os espécimes foram encontrados crescendo sobre solo, em áreas abertas, a $1695 \mathrm{~m}$ de altitude no Sul brasileiro. Nós apresentamos um mapa de distribuição, figuras e comentários.

Palavras-chave: Biodiversidade, campos de altitude, Floresta Atlântica, fungo, líquen

\section{Introduction}

Cladonia P. Browne is one of the most frequently collected lichenized fungi, even by non-lichenologists, and thus reports about the genus have been abundant in recent literature for systematic studies (e.g. PinoBodas et al. 2010, 2011, 2012, Gumboski et al. 2013, Ahti \& Sipman 2013, Yánez-Ayabaca et al. 2013), and new distribution records of various species (e.g. Burgaz \& Ahti 2009, Ahti \& Stenroos 2012, Burgaz \& Pino-Bodas 2012, Flakus et al. 2012, Charnei \& Eliasaro 2013, Yánez-Ayabaca et al. 2013).

Approximately 115 species of Cladonia are known from Brazil (e.g. Vainio 1887, 1894, Ahti et al. 1993, Fleig et al. 1995, Ahti \& Marcelli 1995, Ahti 2000, Stenroos et al. 2002, Gumboski \& Eliasaro 2011, Gumboski et al. 2013) and distributed in various environments. However, the lichenized mycota in many Brazilian regions remain poorly studied, in terms of inventories and ecology.
Previously, Cladonia dimorphoclada was only known from the Eastern United States (e.g. Ahti 1973, Flenniken 1999, Hansen \& Freeman 2003, Thomson 2003, Harris 2004), and also rarely found in southern Mexico, and western Cuba (Ahti 2000). In this paper, we report the occurrence of $C$. dimorphoclada for the first time in South America, more precisely from the Southern region of Brazil.

\section{Material and methods}

Specimens were examined using standard techniques, stereomicroscope, and light microscope. Sections of the thallus and apothecia were mounted in water. Chemical analyses were done according to Huneck \& Yoshimura (1996) and Orange et al. (2001). The distribution map (figure 1) was produced in QGIS Software 2.0.1, according to a tutorial developed by Calegari et al. (2016).

1. Universidade da Região de Joinville, Departamento de Ciências Biológicas, Laboratório de Liquenologia, Campus Universitário s/n, Bom Retiro, 89201-972 Joinville, SC, Brasil

2. Universidade Federal do Mato Grosso do Sul, Instituto de Biociências, Laboratório de Botânica/Liquenologia, Av. Costa e Silva, s.n., 79070-900 Campo Grande, MS, Brasil

3. Universidade Federal de Mato Grosso do Sul, Instituto de Química, Av. Sen. Filinto Müller, 1555, 79074-460 Campo Grande, MS, Brasil

4. Corresponding author. emersongumboski@gmail.com 


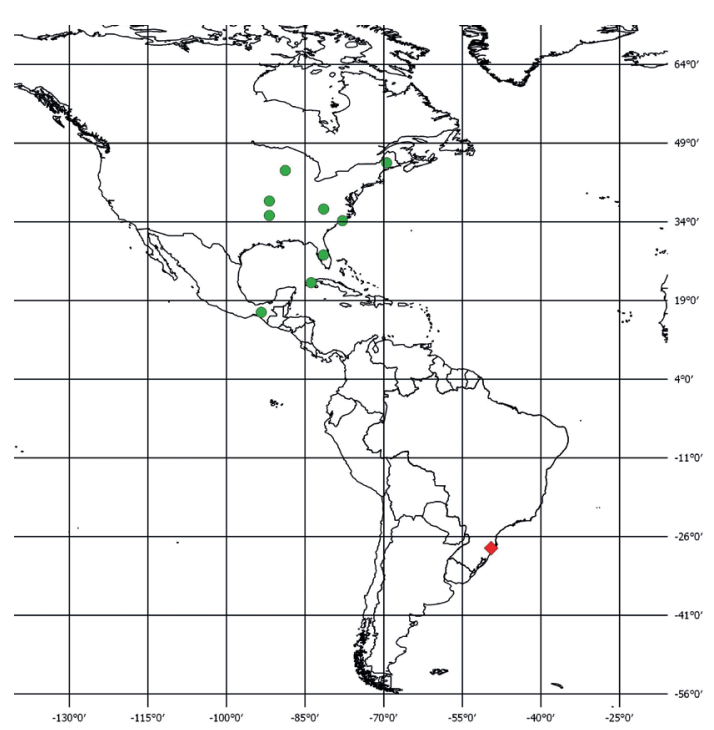

Figure 1. Distribution map of Cladonia dimorphoclada. Green circles: previous records. Red star: new record.

\section{Results and Discussion}

Cladonia dimorphoclada Robbins in Sandstede, Cladon. Exs. 1882. 1929.

Figure 2

Description. Primary thallus not seen. Podetia 1.0-5.0 $\mathrm{cm}$ tall, $0.4-2.0 \mathrm{~mm}$ thick, pale yellowish green, somewhat branched, branching type irregular, anisotomic dichotomy and trichotomy, often with many short outgrowths; axils closed; apices slightly acute, rather slender, erect; not melanotic at base; surface slightly shiny, dull at the base, pruinose near tips, smooth to slightly rough, areolate but not cracked. Podetial wall 130-250 $\mu \mathrm{m}$ thick, cortex rudimentary, $7-12(-25) \mu \mathrm{m}$ thick, medulla intermixed with irregular bundles of stereome, medulla 110-240 $\mu \mathrm{m}$ thick, bundles of stereome $65-100 \mu \mathrm{m}$ in diam., inner surface rough to slightly arachnoid. Conidiomata not seen. Hymenial disks apical, immature.

Chemistry. Spot tests: K-, C-, KC- or KC+ yellow, P-, UV-. TLC and NMR: Usnic acid only.

Distribution and ecology: according to Ahti (2000), in the United States Cladonia dimorphoclada occurs mainly on sandy soils, in Mexico on sandstone rocks, and in Cuba on the coastal white sand. In Brazil, specimens were found growing on top of a rocky outcrop in an open field (figure 3).

Cladonia dimorphoclada can be differentiated from other Brazilian Cladoniae by the few branched thalli with closed axils, the presence of a rudimentary

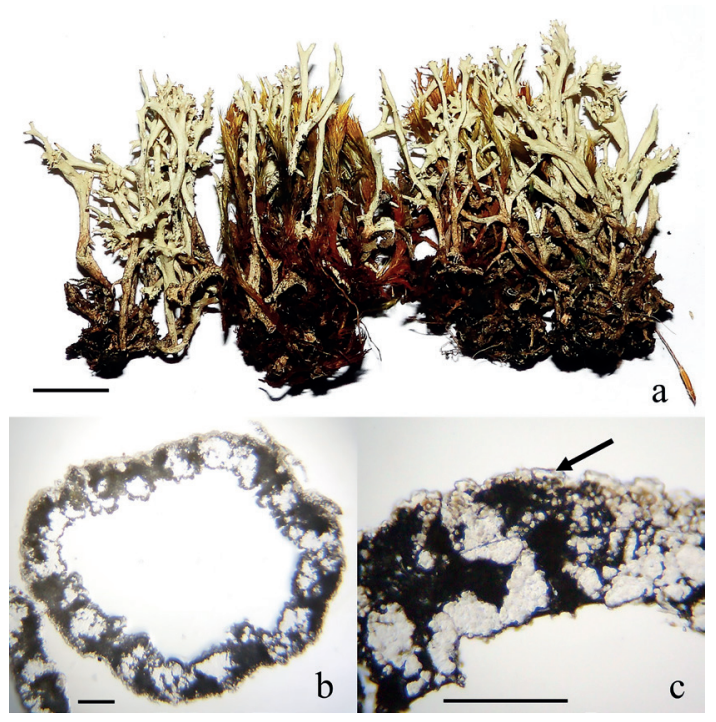

Figure 2. Cladonia dimorphoclada found in Southern Brazil. a. Podetia (JOI). b. Anatomical section of a podetial showing the stereome intermixed with medulla. c. Detail of an anatomical section showing the rudimentary cortex (black arrow). Scale bar: $\mathrm{a}=1 \mathrm{~cm} ; \mathrm{b}, \mathrm{c}=200 \mu \mathrm{m}$.

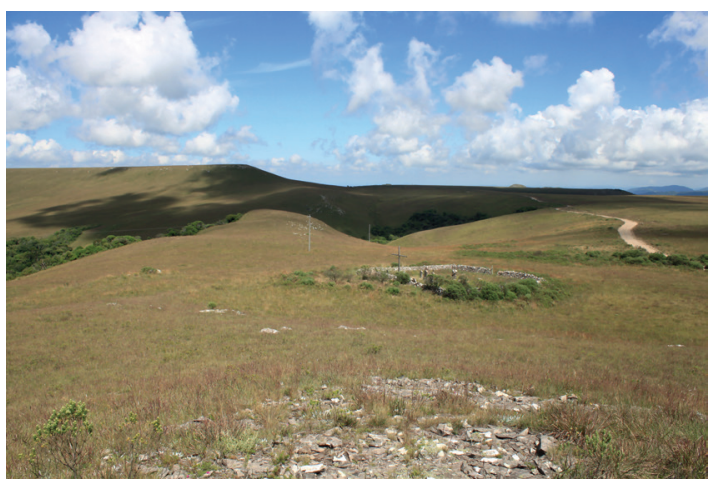

Figure 3. Habitat where Cladonia dimorphoclada was found in Southern Brazil, Municipality of Urubici, São Joaquim National Park.

cortex and stereome intermixed with medulla, and the production of usnic acid as the only secondary compound.

Species with similar morphology and chemistry are Cladonia substellata Vain., C. spinea Ahti, C. uncialis (L.) Weber ex F.H. Wigg. and C. vareschi Ahti. However, C. substellata has moderately to very branched podetia with pale gray necrotic base (Vainio 1887, Ahti 2000); C. spinea form densely branched cushions and present six chemotypes where only usnic acid is constant (Ahti 2000); C. uncialis has a richly branched podetia with a well-developed cortex (Ahti 2000, Burgaz \& Ahti 2009); and C. vareschi has moderately branched podetia with a slender cortex and well-delimited stereome (Ahti 1986, 2000). 
Cladonia apodocarpa Robbins and C. robbinsii A. Evans also present disjunct distribution between North America and temperate South America (Ahti 2000), somewhat like C. dimorphoclada. Cladonia apodocarpa was recorded in North America (e.g. Evans 1947, Harris 2004) and Uruguay (Ahti 2000), and C. robbinsii was recorded in North America (e.g. Flenniken 1999, Thomson 2003, Harris 2004) and South America, in Chile (Galloway \& Quilhot 1998, Ahti 2000), Uruguay and Southern Brazil (Fleig et al. 1995, Ahti 2000).

Material examined: BRAZIL. Santa Catarina: Municipality of Urubici, Parque Nacional de São Joaquim, Campo de Santa Bárbara, in exposed site, rocky outcrop, near an old cemetery, $1695 \mathrm{~m}$ alt., 1-II-2012, leg. A.A. Spielmann \& L.S. Canêz 9978 (CGMS, JOI).

\section{Acknowledgements}

We are grateful to Dr. Teuvo Ahti (Finland) for valuable discussions with the first author about the species identity. We also thank the Conselho Nacional de Desenvolvimento Científico e Tecnológico - CNPq (Process 478705/2010-7) for funding the field trips and sampling for L.S. Canêz and A.A. Spielmann.

\section{Literature cited}

Ahti, T. 1973. Taxonomic notes on some species of Cladonia, subsect. Unciales. Annales Botanici Fennici 10: 163-184.

Ahti, T. 1986. New species and nomenclatural combinations in the lichen genus Cladonia. Annales Botanici Fennici 23: 205-220.

Ahti, T. 2000. Cladoniaceae. Flora Neotropica 78. Organization for Flora Neotropica and New York Botanical Garden, Bronx.

Ahti, T. \& Marcelli., M.P. 1995. Taxonomy of the Cladonia verticillaris complex in South America. In: E.E. Farkas, R. Lücking \& V. Wirth (eds.). Scripta Lichenologica - Lichenological Papers Dedicated to Antonín Vezda. Bibliotheca Lichenologica, pp. 5-26.

Ahti, T. \& Stenroos, S. 2012. New data on nomenclature, taxonomy and distribution of some species of the lichen genus Cladonia. Botanica Complutensis 36: 31-34.

Ahti, T. \& Sipman, H.J.M. 2013. Ten new species of Cladonia (Cladoniaceae, Lichenized Fungi) from the Guianas and Venezuela, South America. Phytotaxa 93: 25-39.
Ahti, T., Stenroos, S. \& Xavier-Filho, L. 1993. The lichen family Cladoniaceae in Paraiba, Pernambuco and Sergipe, Northeast Brazil. Tropical Bryology 7: 55-70.

Burgaz, A.R. \& Ahti, T. 2009. Cladoniaceae. Flora Liquenológica Ibérica. v. 4. Sociedad Española de Liquenología, Madrid.

Burgaz, A.R. \& Pino-Bodas, R. 2012. Notes on species of the genus Cladonia from Bosnia-Herzegovina and Croatia. Botanica Complutensis 36: 13-18.

Calegari, B.B., Delapieve, M.L. \& Sousa, L.M. 2016. Tutorial para preparação de mapas de distribuição geográfica. Boletim, Sociedade Brasileira de Ictiologia 118: $15-30$.

Charnei, A.M. \& Eliasaro, S. 2013. Verticillate Cladonia species (Lichenized Ascomycota) from high-altitude environments of Serra do Mar in Southern Brazil. Hoehnea 40: 87-97.

Evans, A.W. 1947. The Cladoniae of Vermont. The Bryologist 50: 221-246.

Flakus, A., Etayo, J., Schiefelbein, U.L.F., Ahti, T., Jablónska, A., Oset, M., Bach, K., Flakus, P.R. \& Kukwa, M. 2012. Contribution to the knowledge of the lichen biota of Bolivia. 4. Polish Botanical Journal 57: 427-461.

Fleig M., Ahti, T. \& Stenroos, S. 1995. A família Cladoniaceae (liquens) no Rio Grande do Sul, Brasil. Napaea 11: 1-29.

Flenniken, D.G. 1999. The macrolichens in West Virginia: a regional manual of over 275 species illustrated in color. Publ. by the Author, Wooster, Ohio.

Galloway, D.J. \& Quilhot, W. 1998. Checklist of Chilean lichen-forming and lichenicolous fungi. Gayana Botanica 55: 111-185.

Gumboski, E.L. \& Eliasaro, S. 2011. Cladonia litoralis (Cladoniaceae), a new species from southern Brazil. The Bryologist 114: 665-667.

Gumboski, E.L., Beilke, F. \& Eliasaro, S. 2013. Cladonia dunensis sp. nov. from southern Brazil, with notes on the genus in beach dune environments. Mycotaxon 124: 333-340.

Hansen, C.J. \& Freeman, J.D. 2003. A catalog and brief history of the lichen flora of Alabama. Evansia 20: 59-101.

Harris, R.C. 2004. A preliminary list of the lichens of New York. Opuscula Philolichenum 1: 55-74.

Huneck, S. \& Yoshimura, I. 1996. Identification of Lichen Substances. Springer-Verlag, Berlin, Heidelberg.

Orange,A., James, P.W. \& White, F.J. 2001. Microchemical Methods for the Identification of Lichens. British Lichen Society, London. 
Pino-Bodas, R., Burgaz, A.R. \& Martín, M.P. 2010. Elucidating the taxonomic rank of Cladonia subulata versus C. rei (Cladoniaceae). Mycotaxon 113: 311-326.

Pino-Bodas, R., Burgaz, A.R. \& Martín, M.P. \& Lumbsch, H.T. 2011. Phenotypical plasticity and homoplasy complicate species delimitation in the Cladonia gracilis group (Cladoniaceae, Ascomycota). Organisms, Diversity and Evolution 11: 343-355.

Pino-Bodas, R., Burgaz, A.R. \& Martín, M.P. \& Lumbsch, H.T. 2012. Species delimitations in the Cladonia cariosa group (Cladoniaceae, Ascomycota). The Lichenologist 44: 121-135.
Stenroos, S., Hyvonen, J., Myllys, L., Thell, A. \& Ahti, T. 2002. Phylogeny of the genus Cladonia s.lat. (Cladoniaceae, Ascomycetes) inferred from molecular, morphological, and chemical data. Cladistics 18: 237-278.

Thomson, J.W. 2003. Lichens of Wisconsin. Universidade de Wisconsin, Madison.

Vainio, E.A. 1887. Monographia Cladoniarum universalis. I. Acta Societatis pro Fauna et Flora Fennica 4: 1-509.

Vainio, E.A. 1894. Monographia Cladoniarum universalis. II. Acta Societatis pro Fauna et Flora Fennica 10: 1-498.

Yánez-Ayabaca, A., Ahti, T. \& Bungartz, F. 2013. The family Cladoniaceae (Lecanorales) in the Galapagos Islands. Phytotaxa 129: 1-33. 